\title{
ПРОИЗВОДНЫЕ 2-(АДАМАНТ-2-ИЛ)ЭТИЛАМИНА, ОБЛАДАЮЩИЕ ПОТЕНЦИАЛЬНОЙ ПРОТИВОВИРУСНОЙ АКТИВНОСТЬЮ
}

\author{
И.А. Новаков, Б.С. Орлинсон, Е.Н. Савельев, Е.А. Потаёнкова, \\ Н.В. Сидоренко, А.М. Пичугин, М.Н. Ковалева, А.Д. Дубинина
}

Волгоградский госдарственный технический университет, 400005,Россия, г. Волгоград, пр. Ленина, 28.

DOI: 10.19163/MedChemRussia2021-2021-457

E-mail: potaoynkova@vstu.ru

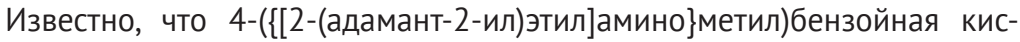
лота, полученная на основе 2-(адамант-2-ил)этиламина является в три раза более эффективным ингибитором HDAC (по сравнению с 1-замещенным аналогом (panHDAC $=0.28$ и раnHDAC $=0.9$ соответственно) и проявляет высокую противораковую активность в отношении трех видов раковых клеток человека (НСT116, NCl-H460 и U251) [1], а 2-адамантилэтиламины проявляют себя как вещества, связывающие рецептор NMDA, а также проявляют себя как анальгетики [2]. В связи с этим, синтез производных 2-(адамант-2-ил)этиламина является актуальной задачей.

Нами были синтезированы производные 2-(адамант-2-ил)этиламина по следующей схеме:
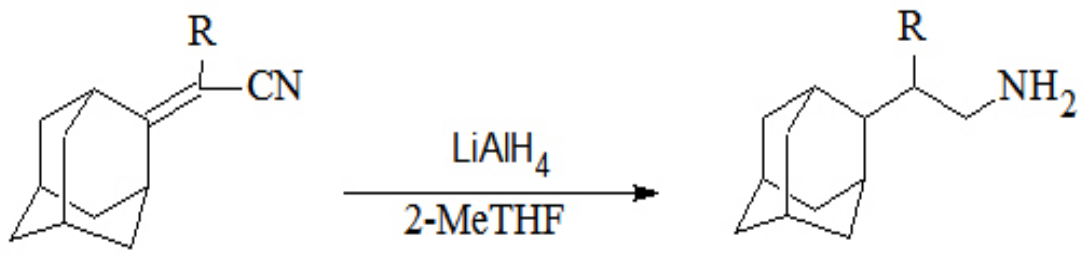

где : $\mathrm{R}=-\mathrm{C}_{3} \mathrm{H}_{7},-\mathrm{C}_{6} \mathrm{H}_{5}$.

Структура полученных соединений подтверждена методами хроматомасс-спектрометрии, ИК- и ЯМР ${ }^{1} \mathrm{H}$ спектроскопии. Выход целевых соединений составил 60-78\%, содержание основного вещества - 98-99\%.

Был проведён вычислительный прогноз возможного наличия различных видов биологической активности и установлено, что полученные производные 2-(адамант-2-ил)этиламина обладают потенциальной противовирусной активностью в отношении вирусов гриппа, пикорновирусов, риновирусов, аденовируса человека.

\section{Литература}

[1] B. Ponpandian, V. Kachhadia, K. Vignesh, Bioorg. Med. Chem. Lett. 2013, 23, 2532-2537.

[2] Pat. EP 1305306B1. Опубл. 24.11.2004]. 